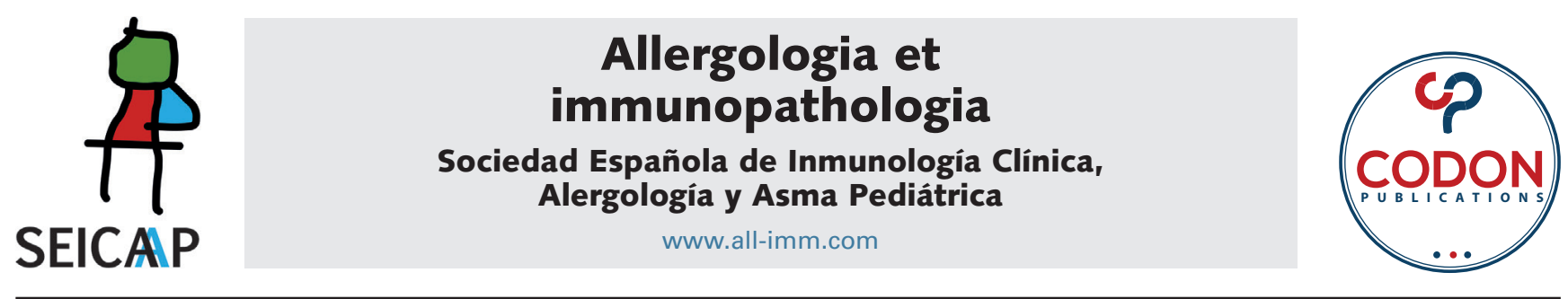

ORIGINAL ARTICLE

OPEN ACCESS @(1)(2)

\title{
Time trends in asthma and atopic diseases in North-West part of Croatia-ISAAC Phase III (2013)
}

\author{
Iva Mrkić Kobal ${ }^{a, b, *}$, Helena Munivrana Škvorcc ${ }^{c, d}$, Marko Škvorce $^{e}$ Štefanija Munivrana ${ }^{f}$
}

aSpecialized in Pediatrics, Subspecialized in Allergology and Clinical Immunology, Outpatient Clinic for Sick Children Dr. Sabol, Zagreb, Croatia

'Student Faculty of Medicine, University of Osijek, Osijek, Croatia

'Assistant Professor, Specialized in Pediatrics, Subspecialized in Allergology and Clinical Immunology, Children's Hospital Srebrnjak ${ }^{d}$ Assistant Professor, University North, Caraždin, Croatia

eSpecialized in Gynecology, Subspecialized in Gynecological Oncology, University Hospital Centre Zagreb, Zagreb, Croatia

fSpecialized in Pediatrics, Subspecialized in Allergology and Clinical Immunology, County Hospital "Cakovec", Cakovec, Croatia

Received: 3 December 2020; Accepted 16 April 2021

Published: 1 July 2021

\section{KEYWORDS \\ allergic rhinitis; asthma; eczema; \\ ISAAC prevalence}

\begin{abstract}
Aim: The authors conducted two cross-sectional studies 8 years apart with the aim of assessing temporal trends in the prevalence of asthma and atopic diseases in Međimurje County, Northwestern Croatia.

Methods: Studies were conducted in children aged 12 years 0 months to 14 years 11 months in 2005 and in 2013; additionally, in adolescents aged 18 years in 2013 according to the international study on asthma and allergies protocol.

Results: In the age group 12-14 years, a significant increase in the prevalence of asthma (5.1\% vs $8.31 \%)$, allergic rhinitis (10.86\% vs $16.24 \%)$, allergic rhinoconjunctivitis (7.14\% vs $10.95 \%$ ) and atopic dermatitis $(5.34 \%$ vs $8.12 \%)$ was observed. When the age group $12-14$ years in 2005 was compared with the age group 18 years in 2013, a significant increase in symptoms of asthma ( $5.1 \%$ vs $11.5 \%)$, allergic rhinitis $(10.86 \%$ vs $19.59 \%)$, allergic rhinoconjunctivitis $(7.14 \%$ vs $14.25 \%)$, and atopic dermatitis $(5.34 \%$ vs $7.69 \%)$ was observed.

Conclusion: This study shows an increasing trend in Međimurje County in the prevalence of all symptoms associated with atopic diseases: Asthma, allergic rhinitis, allergic rhinoconjunctivitis, and atopic dermatitis.

(c) 2021 Codon Publications. Published by Codon Publications.
\end{abstract}

*Corresponding author: Iva Mrkić Kobal, MD, Pediatric Allergist and Clinical Immunologist, Outpatient Clinic for Sick Children dr. Sabol, IV Cvjetno naselje 21, 10000 Zagreb, Croatia. Email address: iva.mrkic@gmail.com 


\section{Introduction}

The encumbrance of asthma and atopic diseases continues to increase worldwide. Together with other atopic diseases, it is the most common chronic disease in children. Most of the data in children come from the Multicenter International Study of Childhood Asthma and Allergies (ISAAC), which provided the standardized methodology for international and interregional data comparison. ISAAC Phase III was a repeat of Phase I, 5 or more years after Phase I, with the aim of examining temporal trends in asthma, allergic rhinitis, and eczema. ${ }^{1,2}$ The studies conducted in Croatia and different Croatian regions show variability in the prevalence of asthma, allergic rhinitis, and atopic dermatitis. ${ }^{3-10}$

The aim of this study was to evaluate the temporal trends in the prevalence of asthma and atopic diseases in children in Međimurje County, northwestern Croatia, by comparing data from children of the same age in the period of 8 years and data from children who performed ISAAC Phase I and Phase III in the period of 8 years.

\section{Materials and methods}

The authors conducted two cross-sectional surveys 8 years apart (Phase I 2005, Phase III 2013) following the ISAAC protocol in the Međimurje region in northwestern Croatia. ${ }^{11}$ This region is located between Eastern Alps and Pannonian Plain, which is characterized by a rural environment. The climate is humid continental, with warm summers and cold winters.

The target population was children aged 12 years 0 months to 14 years 11 months (6th to 8th grade). In 2013, the authors conducted the same survey among adolescents aged 18 years. The total population of children in Međimurje County aged 12 years to 14 years 11 months was 4307. The total population of 18-year-olds was 1545.

Data were collected using a standardized ISAAC written questionnaire. All standardized modules were translated from English to Croatian by physicians specialized in asthma and allergies according to the translation guidelines. ${ }^{12}$

The correctness of the questionnaire was verified by back-translation by an independent professional translator. Ethical approval was obtained from the local ethics committee before the start of the study. Any discrepancies found were clarified through telephone conversations with the parents. Data analysis was performed using MedCalc version 19.5.3. Basic descriptive summaries of the data were made, and differences between the groups studied were calculated by cross-tabulation and the chi-square test. A $p$ value of 0.05 indicated a statistically significant difference.

\section{Results}

The authors included 27 primary schools in the Međimurje region. Phase I included 3111 children and Phase III included 1059 children in the age group of 12 years 0 months to 14 years 11 months. The response rate of Phase I was $84.33 \%$ and that of Phase III was 92.41\%. In 2013, the authors conducted the same survey among 1067 adolescents aged 18 years. The response rate was $94.84 \%$. Descriptive statistics of the study population are shown in Table 1.

(1) Time trends in asthma, allergic rhinitis, and atopic dermatitis prevalence among 12-14-year-old children:

The results of these two studies showing the time trends in the prevalence (\%) of asthma, allergic rhinitis, atopic dermatitis, and their symptoms in 12-14-year-old children (2005 and 2013) are shown in Table 2.

Comparing the results of this study from 2005 with those from 2013, there was a significant increase in the symptom of wheezing ever (11.86 to $21.44 \%, p<0.0001)$ and wheezing in the past 12 months (5.11 to $8.31 \%, p=0.0002$ ). In 2005 , the prevalence was statistically higher in the males; while in 2013, the authors observed no gender difference.

When looking at the changes in the prevalence of rhinitis between 2005 and 2013, a statistically significant increase was observed (10.86 to $16.24 \%, \mathrm{p}<0.0001)$. In 2005 , the prevalence was statistically higher in boys than in girls $(13.82 \%$ in boys vs $10.69 \%$ in girls; odds ratio [OR]: 1.34 , 95\% confidence interval [Cl]: 1.08-1.66, $\mathrm{p}=0.0091$ ), while in 2013 no difference was observed between the genders. The increase is also observed in symptoms of rhinitis combined with conjunctivitis (7.14 to $10.95 \%, p=0.0001$ )

The prevalence of itchy skin rash also increased significantly between 2005 and 2013 (5.34\% vs $8.12 \%, p=0.0011)$. The gender difference changed from a dominant female prevalence (boys: 3.97\%, girls: 6.63\%; OR: 0.58, 95\% Cl: $0.42-0.81, p=0.0013$ ) to a male prevalence (boys: $10.86 \%$, girls: 5.43\%; OR: $2.12,95 \% \mathrm{Cl}: 1.33-3.37, \mathrm{p}=0.0015)$. When considering lifetime eczema, the authors found significantly higher rates in girls (boys $11.24 \%$ vs $16.10 \%$ in girls; OR: 0.66 , 95\% Cl: 0.46-0.94, $\mathrm{p}=0.0219$ ).

The gender differences in the prevalence of asthma, allergic rhinitis, atopic dermatitis, and their symptoms are shown in Table 3.

(2) Time trends in the prevalence of asthma, allergic rhinitis, and atopic dermatitis between 12-14-old children in 2005 and 18-year-old participants in 2013

The results of the two studies showing the time trends in the prevalence (\%) of asthma, allergic rhinitis, atopic dermatitis and their symptoms in 12-14-year-olds and 18-year-olds (2005 and 2013) are shown in Table 4.

Table 1 Descriptive statistics of the study population.

\begin{tabular}{|c|c|c|c|c|c|c|c|}
\hline \multirow[b]{3}{*}{ Survey } & \multicolumn{6}{|c|}{ 12-14-year-old children } & \multirow{3}{*}{$\begin{array}{c}\text { Response } \\
\text { rate (\%) }\end{array}$} \\
\hline & \multicolumn{2}{|c|}{ Boys } & \multicolumn{2}{|c|}{ Girls } & \multicolumn{2}{|c|}{ Total } & \\
\hline & $\mathrm{N}$ & $\%$ & $\mathrm{~N}$ & $\%$ & $\mathrm{~N}$ & $\%$ & \\
\hline 2005 & 1512 & 48.86 & 1599 & 51.14 & 3111 & 100 & 94.33 \\
\hline \multirow[t]{4}{*}{2013} & 525 & 49.58 & 534 & 50.42 & 1059 & 100 & 92.41 \\
\hline & \multicolumn{6}{|c|}{ 18-years-old children } & \\
\hline & \multicolumn{2}{|c|}{ Boys } & \multicolumn{2}{|c|}{ Girls } & \multicolumn{2}{|c|}{ Total } & \\
\hline & $\mathrm{N}$ & $\%$ & $\mathrm{~N}$ & $\%$ & $\mathrm{~N}$ & $\%$ & \\
\hline 2013 & 531 & 49.77 & 536 & 30.23 & 1067 & 100 & 94.86 \\
\hline
\end{tabular}


Table 2 Time trends in the prevalence (\%) of asthma, allergic rhinitis, atopic dermatitis, and their symptoms in 12-14-year-old children (2005 and 2013).

\begin{tabular}{|c|c|c|c|c|c|}
\hline & \multicolumn{5}{|c|}{ 12-14-year-old children } \\
\hline & \multicolumn{2}{|c|}{2005} & \multicolumn{2}{|c|}{2013} & \multirow[b]{4}{*}{$\mathrm{p}^{*}$} \\
\hline & \multicolumn{2}{|c|}{ Total } & \multicolumn{2}{|c|}{ Total } & \\
\hline & \multicolumn{2}{|c|}{$N=3111$} & \multicolumn{2}{|c|}{$N=1059$} & \\
\hline & $\mathrm{N}$ & $\%$ & $\mathrm{~N}$ & $\%$ & \\
\hline Wheezing ever & 369 & 11.86 & 227 & 21.44 & $<0.0001$ \\
\hline Wheezing in the past year & 159 & 5.11 & 88 & 8.31 & $=0.0002$ \\
\hline Exercise-induced wheezing in the past year & 225 & 7.23 & 105 & 9.92 & 0.0054 \\
\hline Night wheezing in the past year & 72 & 2.31 & 28 & 2.64 & 0.5451 \\
\hline Dry night cough in the past year & 209 & 6.71 & 126 & 11.89 & $<0.0001$ \\
\hline Asthma ever & 220 & 7.07 & 98 & 9.25 & 0.0212 \\
\hline Rhinitis symptoms ever & 660 & 12.21 & 192 & 18.31 & 0.0317 \\
\hline Rhinitis symptoms in the past year & 338 & 10.86 & 172 & 16.24 & $<0.0001$ \\
\hline Rhinoconjunctivitis symptoms in the past year & 222 & 7.14 & 116 & 10.95 & 0.0001 \\
\hline Itchy rash ever & 218 & 7.01 & 145 & 13.69 & $<0.0001$ \\
\hline Itchy rash in the past year & 166 & 5.34 & 86 & 8.12 & 0.0011 \\
\hline Atopic eczema ever & 335 & 10.77 & 135 & 12.75 & 0.0788 \\
\hline
\end{tabular}

Bold values present statistically significant results

Table 3 Prevalence (\%) of asthma, allergic rhinitis, atopic dermatitis, and their symptoms in 12-14-year-old children (2005 and 2013) according to gender.

\begin{tabular}{|c|c|c|c|c|c|c|c|c|c|c|}
\hline & \multicolumn{10}{|c|}{ 12-14-year-old group } \\
\hline & \multicolumn{4}{|c|}{2005} & & \multicolumn{4}{|c|}{2013} & \multirow[b]{5}{*}{$\mathrm{p}$} \\
\hline & \multicolumn{4}{|c|}{ Total $N=3111$} & & \multicolumn{4}{|c|}{ Total $N=1059$} & \\
\hline & \multirow{2}{*}{\multicolumn{2}{|c|}{$\begin{array}{c}\text { Male } \\
\mathrm{N}=1512\end{array}$}} & \multirow{2}{*}{\multicolumn{2}{|c|}{$\begin{array}{c}\text { Female } \\
N=1599\end{array}$}} & \multirow[b]{3}{*}{$\mathrm{p}$} & \multirow{2}{*}{\multicolumn{2}{|c|}{$\begin{array}{c}\text { Male } \\
N=525\end{array}$}} & \multirow{2}{*}{\multicolumn{2}{|c|}{$\begin{array}{c}\text { Female } \\
N=534\end{array}$}} & \\
\hline & & & & & & & & & & \\
\hline & $\mathrm{N}$ & $\%$ & $\mathrm{~N}$ & $\%$ & & $\mathrm{~N}$ & $\%$ & $\mathrm{~N}$ & $\%$ & \\
\hline Wheezing ever & 213 & 14.09 & 156 & 9.76 & 0.0002 & 123 & 23.43 & 104 & 19.48 & 0.1212 \\
\hline Wheezing in the past year & 85 & 5.62 & 74 & 4.63 & 0.2394 & 47 & 8.95 & 41 & 7.68 & 0.6358 \\
\hline $\begin{array}{l}\text { Exercise-induced wheezing in the } \\
\text { past year }\end{array}$ & 108 & 7.14 & 117 & 7.31 & 0.9059 & 56 & 10.67 & 49 & 9.18 & 0.5302 \\
\hline Night wheezing in the past year & 35 & 2.31 & 37 & 2.31 & 0.9063 & 31 & 5.90 & 29 & 5.43 & 0.7387 \\
\hline Dry night cough in the past year & 107 & 7.08 & 102 & 6.38 & 0.4806 & 62 & 11.81 & 64 & 11.99 & 0.9297 \\
\hline Asthma ever & 123 & 8.13 & 97 & 6.07 & 0.0293 & 58 & 11.05 & 40 & 7.49 & 0.0471 \\
\hline Rhinitis symptoms ever & 209 & 13.82 & 171 & 10.69 & 0.0091 & 93 & 17.71 & 99 & 18.54 & 0.7275 \\
\hline Rhinitis symptoms in the past year & 180 & 11.90 & 158 & 9.88 & 0.0792 & 86 & 16.38 & 86 & 16.10 & 0.9031 \\
\hline $\begin{array}{l}\text { Rhinoconjunctivitis symptoms in } \\
\text { the past year }\end{array}$ & 115 & 7.61 & 107 & 6.69 & 0.3574 & 56 & 10.67 & 60 & 11.24 & 0.7668 \\
\hline Itchy rash ever & 83 & 5.49 & 135 & 8.44 & 0.0016 & 59 & 11.24 & 86 & 16.10 & 0.0219 \\
\hline Itchy rash in the past year & 60 & 3.97 & 106 & 6.63 & 0.0013 & 57 & 10.86 & 29 & 5.43 & 0.0015 \\
\hline Atopic eczema ever & 140 & 9.26 & 195 & 12.2 & 0.0098 & 57 & 10.86 & 78 & 14.61 & 0.0682 \\
\hline
\end{tabular}

* $P$ values for the difference between genders

Bold values present statistically significant results

The results presented in Table 4 show a statistically significant increase in 18-year-olds in 2013 compared to 12-14-year-olds in 2005 for all asthma symptoms: Wheeze ever $(11.86 \%$ vs $20.89 \%$, OR: $0.51,95 \% \mathrm{Cl}: 0.42-0.61, \mathrm{p}<$ 0.0001 ), wheeze last year (5.11\% vs $11.15 \%$, OR: $0.43,95 \% \mathrm{Cl}$ : $0.33-0.55, \mathrm{p}<0.0001$ ), exertional wheezing in the past year
(7.23\% vs. $10.78 \%$, OR: $0.65,95 \% \mathrm{Cl}: 0.51-0.82, \mathrm{p}=0.0003)$, dry nocturnal cough in the past year $(6.71 \%$ vs. $11.43 \%$, OR: 0.56, 95\% Cl: 0.44-0.71, $\mathrm{p}<0.0001$ ), and asthma ever (OR: $0.74,95 \% \mathrm{Cl}: 0.58-0.95, \mathrm{p}=0.0195)$. Regarding allergic rhinitis symptoms, the authors observed a statistically significant increase in the prevalence of rhinitis symptoms in the 
Table 4 Time trends in the prevalence (\%) of asthma, allergic rhinitis, atopic dermatitis, and their symptoms in 12-14-year-old children (2005) and in 18-year-old participants (2013).

\begin{tabular}{|c|c|c|c|c|c|}
\hline & \multicolumn{2}{|c|}{$\begin{array}{l}\text { 12-14-year-old } \\
\text { children }\end{array}$} & \multicolumn{2}{|c|}{$\begin{array}{l}\text { 18-year-old } \\
\text { children }\end{array}$} & \multirow[t]{5}{*}{$\mathrm{p}^{*}$} \\
\hline & \multicolumn{2}{|c|}{2005} & \multicolumn{2}{|c|}{2013} & \\
\hline & \multicolumn{2}{|c|}{ Total } & \multicolumn{2}{|c|}{ Total } & \\
\hline & \multicolumn{2}{|c|}{$N=3111$} & \multicolumn{2}{|c|}{$N=1067$} & \\
\hline & $\mathrm{N}$ & $\%$ & $\mathrm{~N}$ & $\%$ & \\
\hline Wheezing ever & 369 & 11.86 & 223 & 20.89 & $<0.0001$ \\
\hline Wheezing in the past year & 159 & 5.11 & 119 & 11.15 & $<0.0001$ \\
\hline Exercise-induced wheezing in the past year & 225 & 7.23 & 115 & 10.78 & 0.0003 \\
\hline Night wheezing in the past year & 72 & 2.31 & 36 & 3.37 & 0.0613 \\
\hline Dry night cough in the past year & 209 & 6.71 & 122 & 11.43 & $<0.0001$ \\
\hline Asthma ever & 220 & 7.07 & 99 & 9.28 & 0.0195 \\
\hline Rhinitis symptoms ever & 660 & 12.21 & 236 & 22.12 & 0.5352 \\
\hline Rhinitis symptoms in the past year & 338 & 10.86 & 209 & 19.59 & $<0.0001$ \\
\hline Rhinoconjunctivitis symptoms in the past year & 222 & 7.14 & 152 & 14.25 & $<0.0001$ \\
\hline Itchy rash ever & 218 & 7.01 & 129 & 12.09 & $<0.0001$ \\
\hline Itchy rash in the past year & 166 & 5.34 & 82 & 7.69 & 0.0053 \\
\hline Atopic eczema ever & 335 & 10.77 & 135 & 12.65 & 0.0932 \\
\hline
\end{tabular}

last 12 months $(10.86 \%$ vs. $19.59 \%$, OR: $0.50,95 \% \mathrm{Cl}: 0.41-$ $0.60, p<0.0001)$ and rhinoconjunctivitis symptoms $(7.14 \%$ vs.14.25\%, OR: $0.46,95 \% \mathrm{Cl}: 0.37-0.58, \mathrm{p}<0.0001)$.

For atopic dermatitis in 18-year-olds, the authors observed a statistically significant increase in the prevalence of symptoms for both itchy rash ever $\mathbf{( 7 . 0 1 \%}$ vs 12.09\%, OR: $0.49,95 \% \mathrm{Cl}: 0.39-0.61, \mathrm{p}<0.0001)$ and itchy rashes in the past 12 months $(5.34 \%$ vs. $7.69 \%$, OR: 0.68 , 95\% $\mathrm{Cl}: 0.51-0.89, \mathrm{p}=0.0053)$.

The gender differences in the prevalence of asthma, allergic rhinitis, atopic dermatitis, and their symptoms among 12-14-year-old participants in 2005 and 18-year-old participants in 2013 are shown in Table 5.

A statistically significant difference between genders was found for symptoms like wheezing ever in life (male: 17.89\%, female: $23.88 \%$; OR: 0.69 , 95\% Cl: 0.52-0.94, $\mathrm{p}=$ 0.0164 ), wheezing in the last year (male: $7.53 \%$, female: 14.74\%; OR: 0.47 , 95\% Cl: 0.32-0.70, $p=0.0002$ ), exertion-induced wheezing in the past 12 months (men: $5.84 \%$, women: $15.67 \%$; OR: $0.33,95 \% \mathrm{Cl}: 0.22-0.51, \mathrm{p}=0.0001$ ), and dry nocturnal cough in the past 12 months (men: 8.66\%, women: $14.18 \%$; OR: 0.57 , 95\% Cl: $0.39-0.85, \mathrm{p}=$ 0.005). According to gender, the authors also observed significant gender differences for all symptoms of rhinitis: Rhinitis symptoms ever (male: 19.21\%, female: 25\%; OR: $0.72,95 \% \mathrm{Cl}: 0.53-0.96, \mathrm{p}=0.00240$ ), rhinitis symptoms in the past year (male: $17.14 \%$, female: $22.01 \%$; OR: 0.73 , 95\% $\mathrm{Cl}$ : 0.54-0.99, $\mathrm{p}=0.0452$ ) and rhinoconjunctivitis symptoms in the past year (male: 12.05\%, female: 16.42\%; OR: 0.69, 95\% Cl: $0.49-0.99, \mathrm{p}=0.0421)$. Itchy rashes in the past year were also more common in women (men: $5.08 \%$, women: 10.26\%; OR: 0.47, 95\% Cl: 0.29-0.76, $\mathrm{p}=0.0018$ ), as well as reported itchy rashes ever in their lifetime (men: $8.85 \%$, women: $16.42 \%$; OR: $0.49,95 \% \mathrm{Cl}: 0.34-0.72, \mathrm{p}=0.0002$ )

\section{Discussion}

By strictly applying identical study methods, achieving high and similar response rates in both surveys and for both age groups in a large sample representative of children in the general population, the authors believe that they have arrived at credible estimates of temporal trends in the prevalence of asthma symptoms and symptoms of allergic rhinitis, rhinoconjunctivitis, and atopic eczema in the population studied.

The results of this study show an increase in the time trends of all symptoms associated with atopic diseases and lifetime prevalence of asthma in children in Međimurje County.

The advantage of this study is the comparison of the prevalence of atopic symptoms in the age group of 18 years in 2013 with the age group of 12-4 years 11 months in 2005 as the 8-year difference between the studies shows a temporal trend in approximately the same population in the same area at different time points (Table 4). The disadvantage is the smaller number of participants in Phase III, due to limited funding.

The prevalence of wheezing in the last 12 months in the 13-14 age group had increased over the period 20052013, with a marked increase in girls. In 2005, wheezing symptoms in the last 12 months were predominantly found in boys and in 2013. The authors found no gender dominance.

The results of this study showed a similar temporal trend in the prevalence of asthma symptoms compared with other Croatian Counties, which published the results of the ISAAC Phase III. ${ }^{8,9}$ Compared with Primorsko Goranska County, in Međimurje County the prevalence of asthma ever in life, wheezing ever in life is higher, although 
Table 5 Prevalence (\%) of asthma, allergic rhinitis, atopic dermatitis, and their symptoms in 12-14-year-old children (2005 and 2013) and in 18-year-old children (2013) according to gender.

\begin{tabular}{|c|c|c|c|c|c|c|c|c|c|c|}
\hline & \multicolumn{4}{|c|}{ 12-14-years-old } & & \multicolumn{4}{|c|}{ 18-years-old } & \\
\hline & \multicolumn{4}{|c|}{2005} & & \multicolumn{4}{|c|}{2013} & \\
\hline & \multicolumn{4}{|c|}{ Total $N=3111$} & & \multicolumn{4}{|c|}{ Total $N=1067$} & \\
\hline & \multicolumn{2}{|c|}{ Male } & \multicolumn{2}{|c|}{ Female } & & \multicolumn{2}{|c|}{ Male } & \multicolumn{2}{|c|}{ Female } & \multirow[b]{3}{*}{ p } \\
\hline & \multicolumn{2}{|c|}{$N=1512$} & \multicolumn{2}{|c|}{$N=1599$} & \multirow[b]{2}{*}{$\mathrm{p}$} & \multicolumn{2}{|c|}{$N=531$} & \multicolumn{2}{|c|}{$N=536$} & \\
\hline & $\mathrm{N}$ & $\%$ & $\mathrm{~N}$ & $\%$ & & $\mathrm{~N}$ & $\%$ & $\mathrm{~N}$ & $\%$ & \\
\hline Wheezing ever & 213 & 14.09 & 156 & 9.76 & 0.0002 & 95 & 17.89 & 128 & 23.88 & 0.0164 \\
\hline Wheezing in the past year & 85 & 5.62 & 74 & 4.63 & 0.2394 & 40 & 7.53 & 79 & 14.74 & 0.0002 \\
\hline $\begin{array}{l}\text { Exercise-induced wheezing in the } \\
\text { past year }\end{array}$ & 108 & 7.14 & 117 & 7.31 & 0.9059 & 31 & 5.84 & 84 & 15.67 & $<0.0001$ \\
\hline Night wheezing in the past year & 35 & 2.31 & 37 & 2.31 & 0.9063 & 34 & 6.40 & 49 & 9.14 & 0.0965 \\
\hline Dry night cough in the past year & 107 & 7.08 & 102 & 6.38 & 0.4806 & 46 & 8.66 & 76 & 14.18 & 0.005 \\
\hline Asthma ever & 123 & 8.13 & 97 & 6.07 & 0.0293 & 47 & 8.85 & 52 & 9.70 & 0.6323 \\
\hline Rhinitis symptoms ever & 209 & 13.82 & 171 & 10.69 & 0.0091 & 102 & 19.21 & 134 & 25 & 0.0240 \\
\hline Rhinitis symptoms in the past year & 180 & 11.90 & 158 & 9.88 & 0.0792 & 91 & 17.14 & 118 & 22.01 & 0.0452 \\
\hline $\begin{array}{l}\text { Rhinoconjunctivitis symptoms in } \\
\text { the past year }\end{array}$ & 115 & 7.61 & 107 & 6.69 & 0.3574 & 64 & 12.05 & 88 & 16.42 & 0.0421 \\
\hline Itchy rash ever & 83 & 5.49 & 135 & 8.44 & 0.0016 & 49 & 9.28 & 80 & 14.93 & 0.0047 \\
\hline Itchy rash in the past year & 60 & 3.97 & 106 & 6.63 & 0.0013 & 27 & 5.08 & 55 & 10.26 & 0.0018 \\
\hline Atopic eczema ever & 140 & 9.26 & 195 & 12.2 & 0.0098 & 47 & 8.85 & 88 & 16.42 & 0.0002 \\
\hline
\end{tabular}

Bold values present statistically significant results

the prevalence of wheezing in the last 12 months is higher in Primorsko Goranska County with male dominance. According to the Croatian authors of Primorsko Goranska County, this may be due to the high proportion of adolescents and school children who smoke. ${ }^{8}$ Since adolescence is a very demanding phase of life, it is possible that boys at this age experimentally smoke more than girls. ${ }^{13}$

The prevalence of wheezing in Brod Posavina County is similar to the prevalence of wheezing in Međimurje County. ${ }^{9}$

Compared with other studies based on the ISAAC questionnaire, the increase in asthma prevalence is similar to other low- and middle-income countries that have not yet reached the plateau. ${ }^{1,14,15}$ In Phase III of ISAAC, 12-month prevalence of asthma symptoms in adolescents was reported, ranging from $2.1 \%$ in Indonesia to $32.2 \%$ in the United Kingdom. The highest 12-month prevalence of wheeze was found in westernized, English-speaking countries. ${ }^{16}$ Among the most important established risk factors for asthma and wheeze in general is sensitization to house dust mites, which has a high prevalence in Međimurje County and it may be one of the reasons for the increase in the prevalence of all atopic diseases. ${ }^{16,17}$

The lifetime prevalence of rhinitis symptoms has also increased, but with a higher increase than rhinitis with conjunctivitis. This suggests the role of other possible causes of rhinitis symptoms (infection, physical stimuli, air quality), while rhinitis and conjunctivitis are better markers of allergic symptoms. ${ }^{18}$ Allergic rhinitis and conjunctivitis have also shown a temporal increase in prevalence in Međimurje County, as in other Croatian regions. ${ }^{7,9}$ The increase in 12-14-year-olds is equally observed in both gender. A similar increase without gender dominance in the same age group was reported in children in a German study from Muenster. ${ }^{19}$

Symptoms of atopic dermatitis also showed a significant increase from 2005 to 2013, and in both studies, symptoms were more severe in girls. The results show that the prevalence of atopic dermatitis is higher than that of itchy rashes in general, which is probably due to the fact that the memory of childhood itching has been lost and parents only remember the diagnosis of atopic dermatitis. Compared with other Croatian regions, Međimurje County showed a slight increase in symptoms of atopic dermatitis in the last 12 months, while the prevalence in Brod Posavina County and Primorsko Goranska County remained stable. ${ }^{7,9}$ Previously published data from Međimurje County showed the following risk factors: Atopy in the family, female gender, and sleeping on feather pillows. ${ }^{20}$

If children aged 13-14 years in 2005 are compared with young adults aged 18 years in 2013, the authors find that wheezing is even more common in girls. This highlights the increase in the prevalence of wheezing in girls over time. It is consistent with previous studies on gender difference in asthma prevalence showing an increase in asthma symptoms in female adolescents. ${ }^{19,21-23}$ This is thought to be related to immunological and hormonal factors and differences in gender-specific responses to environmental factors..$^{24,25}$ In addition to wheezing overall, the prevalence of wheezing was also higher in female gender, including exertion-induced wheezing and dry night cough in the last year.

The predominance of female gender in allergic rhinitis also increases with age. This result is observed in this study as well as in other studies. Frolich et al. and Pinart have shown the same gender shift in the prevalence of allergic rhinitis toward adulthood. ${ }^{22,26}$ 


\section{Conclusion}

In this study, the authors show an increasing trend in the prevalence of all symptoms associated with atopic diseases: Asthma, allergic rhinitis, allergic rhinoconjunctivitis, and eczema, as well as the lifetime prevalence of asthma in Međimurje County. The overall prevalence of asthma in Međimurje County has remained moderate, as it has the prevalence of atopic eczema, while the prevalence of allergic rhinitis has increased and remains high. These data provide important information for further interventions in the public health system.

\section{Conflict of interests}

The authors declare no potential conflicts of interest with respect to research, authorship and/or publication of this article.

\section{References}

1. Asher MI, Montefort S, Bjorksten B, Lai CK, Strachan DP, Weiland SK, et al. Worlwide time trends in the prevalence of symptoms of asthma, allergic rhinoconjunctivitis, and eczema in childhood: ISAAC Phases One and Three repeat multicountry cross-sectional surveys. Lancet. 2006;368(9537):733-743. https://doi.org/10.1016/S0140-6736(06)69283-0

2. Bjorksten B, Clayton T, Ellwood P, Stewart A, Strachan D, ISAAC Phase III Study Group. Worldwide time trends for symptoms of rhinitis and conjunctivitis: Phase III of the International Study of Asthma and Allergies in Childhood. Pediatr Allergy Immunol. 2008;19(2):110-124. https://doi. org/10.1111/j.1399-3038.2007.00601.x

3. Munivrana H, Vorko-Jovic A, Munivrana S, Kursar M, MedlobiGluhak M, Vlahek P. The prevalence of allergic diseases among Croatian school children according to the ISAAC Phase One questionnaire. Med Sci Monit. 2007;13(1):505-509.

4. Drkulec V, Tesari H, Tomic-Rajic M, Navratil M, Plavec D., Nogalo B. et al. The prevalence of asthma, allergic rhinitis/ rhinoconjunctivitis and atopic eczema among Croatian school children in Pozesko-Slavonska County (ISAAC phase I). In: Stipic-Marković A, Cvoriscec B, editors. Proceedings of the 1st Croatian Congress of Allergollogy and Clinical Immunology. 2009 May 21-23; Zagreb, Croatia. p. 19.

5. Stipic-Markovic A, Cvoriscec B, Pevec B, Radulovic-Pevec M. Increasing incidence of allergy in Croatia. Rad Med Sci Zagreb. 2008;499:105-116.

6. Stipic-Markovic A, Pevec B, Radulovic-Pevec M, Custovic A. Prevalence of symptoms of asthma, allergic rhinitis, conjunctivitis and atopic eczema: ISAAC in a population of school children in Zagreb [in Croatian]. Acta Med Croatica. 2003;57:281-285.

7. Banac S, Lah-Tomulić K, Ahel V, Rozmanić V, Simundić N, Zubović S, et al. Prevalence of asthma and allergic diseases in Croatian children is increasing: Survey study. Croat Med J. 2004;45:721-726.

8. Banac S, Rozmanic V, Manestar K, Korotaj-Rozmanic Z, Lah-Tomulick, Vidovic I, et al. Rising trends in the prevalence of asthma and allergic diseases among school children in the north-west coastal part of Croatia. J Asthma. 2013;50(8):810814. https://doi.org/10.3109/02770903.2013.803115

9. Aberle N, Kljaić Bukvić B, Blekić M, Vučković M, Bardak D, Gudelj A, et al. Allergic diseases and atopy among schoolchildren in Eastern Croatia. Acta Clin Croatica. 2018;57(1):82-90. https://doi.org/10.20471/acc.2018.57.01.09

10. Gudelj I, Mrkić Kobal I, Munivrana Škvorc H, Miše K, Vrbica Z, Plavec D, et al. Intraregional differences in asthma prevalence and risk factors for asthma among adolescents in SplitDalmatia County, Croatia. Med Sci Monit. 2012:18(4):43-50. https://doi.org/10.12659/MSM.882609

11. Asher MI, Keil U, Anderson HR, Beasley R, Crane J, Martinez F, et al. International Study of Asthma and Allergies in Childhood (ISAAC): Rationale and methods. Eur Respir J. 1995;8(3):483491. https://doi.org/10.1183/09031936.95.08030483

12. Weiland SK, Beasley R, Strachan D. Guidelines for the translation of questionnaires. Münster, Germany: ISAAC Phase One Coordinating Committee; 1993.

13. Kuzman M, Pejnovi ć Franelić I, Pavi ć Š imetin I, Pejak M. European school survey project on alcohol and other drugs: Report for Republic of Croatia and the city of Zagreb. Zagreb: Hrvatski zavod za javno zdravstvo, Grad Zagreb; 2008. Change in habits among students in period 1995-2007. p. 43.

14. Pearce N, Ait-Khaled N, Beasley R, Mallol J, Keil U, Mitchell E, et al. Worldwide trends in the prevalence of asthma symptoms: Phase III of the International Study of Asthma and Allergies in Childhood (ISAAC). Thorax. 2007;62(9):758-766. https://doi.org/10.1136/thx.2006.070169

15. Dharmage SC, Perret JL, Custovic A. Epidemiology of asthma in children and adults. Front Pediatr. 2019;7:2296-2360. https://doi.org/10.3389/fped.2019.00246

16. Kuruvilla ME, Vanijcharoenkarn K, Shih JA, Lee FEH. Epidemiology and risk factors for asthma. Respir Med. 2019;149:16-22. https://doi.org/10.1016/j.rmed.2019.01.014

17. Munivrana Škvorc H. Risk factors for atopy diseases in schoolchildren. PhD thesis; 2014. Faculty of Medicine, University of Zagreb, http://medlib.mef.hr/2130

18. Bjorksten B, Clayton T, Ellwood P, Stewart A, Strachan D, The ISAAC Phase III Study Group. Worldwide time trends for symptoms of rhinitis and conjunctivitis: Phase III of the International Study of Asthma and Allergies in Childhood. Pediatr Allergy Immunol. 2008;19(2):110-124. https://doi. org/10.1111/j.1399-3038.2007.00601.x

19. Maziak W, Behrens T, Brasky TM, Duhme H, Rzehak P, Weiland SK, et al. Are asthma and allergies in children and adolescents increasing? Results from ISAAC phase I and phase III surveys in Munster, Germany. Allergy. 2003;58(7):572-579. https://doi. org/10.1034/j.1398-9995.2003.00161.x

20. Munivrana Skvorc H, Plavec D, Munivrana S, Skvorc M, Nogalo B, Turkalj $M$. Prevalence of and risk factors for the development of atopic dermatitis in schoolchildren aged 12-14 in northwest Croatia. Allergologia Et Immunopathologia. 2014;42(2):142148. https://doi.org/10.1016/j.aller.2012.10.008

21. Haidinger G, Waldhor T, Meusburger S, Suss G, Vutuc C. The prevalence of childhood asthma and of allergies in 7 districts of Upper Austria-ISAAC III. Allergologie. 2008;31:17-22. https://doi.org/10.5414/ALP31017

22. Frohlich M, Pinart M, Keller T, Reich A, Cabieses B, Hohmann C, et al. Is there a sex-shift in prevalence of allergic rhinitis and comorbid asthma from childhood to adulthood? A meta-analysis. Clin Transl Allergy. 2017;7:9. https://doi.org/10.1186/s13601017-0176-5

23. Ferrante G, La Grutta S. The burden of pediatric asthma. Front Pediatr. 2018;6:7. https://doi.org/10.3389/fped.2018.00186

24. Zein JG, Erzurum SC. Asthma is different in women. Curr Allergy Asthma Rep. 2015;15:10. https://doi.org/10.1007/s11882015-0528-y

25. Kalm-Stephens P, Nordvall L, Janson C, Neuman A, Malinovschi A, Alving K. Different baseline characteristics are associated with incident wheeze in female and male adolescents. Acta Paediatr. 2020;109(11):2324-2331. https://doi.org/10.1111/apa. 15263

26. Pinart M, Keller T, Reich A, Frohlich M, Cabieses B, Hohmann C, et al. Sex-related allergic rhinitis prevalence switch from childhood to adulthood: A systematic review and metaanalysis. Int Arch Allergy Immunol. 2017;172(4):224-235. https://doi.org/10.1159/000464324 